\title{
Growth and hematological responses of tambaqui, Colossoma macropomum fed different levels of rice, Oryza spp.
}

\author{
P. H. R. Aride (D), A. M. Oliveirab (D), M. S. Ferreira ${ }^{b}$ (D), A. R. S. Lieblc (D),

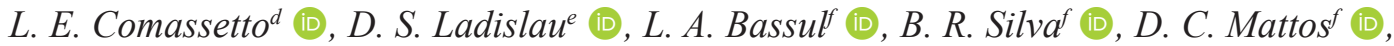

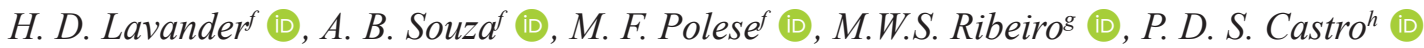 \\ and A. T. Oliveira ${ }^{a *}$ (1) \\ ${ }^{a}$ Instituto Federal de Educação, Ciência e Tecnologia do Amazonas - IFAM, Campus Manaus Centro - CMC, Manaus, \\ AM, Brasil \\ 'Instituto Nacional de Pesquisas da Amazônia - INPA, Laboratório de Ecofisiologia e Evolução Molecular, Manaus, AM, Brasil \\ 'Universidade Federal do Amazonas - UFAM, Programa de Pós-graduação em Ciências Pesqueiras nos Trópicos - CIPET, \\ Manaus, AM, Brasil \\ dInstituto Federal de Educação, Ciência e Tecnologia de Roraima - IFRR, Campus Amajari, Amajari, RR, Brasil \\ eUniversidade Estadual do Oeste do Paraná - UNIOESTE, Programa de Pós-graduação em Recursos Pesqueiros e \\ Engenharia de Pesca - PREP, Toledo, PR, Brasil \\ fInstituto Federal de Educação, Ciência e Tecnologia do Espírito Santo - IFES, Campus Piúma, Piúma, ES, Brasil \\ ${ }^{\mathrm{g}}$ Instituto Nacional de Pesquisas da Amazônia - INPA, Universidade Nilton Lins, Programa de Pós-graduação em \\ Aquicultura, Manaus, AM, Brasil

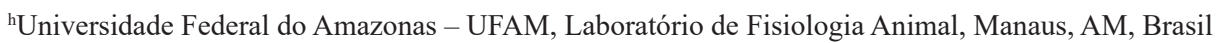 \\ *e-mail: adriano.oliveira@ifam.edu.br
}

Received: December 27, 2019 - Accepted: June 1, 2020 - Distributed: November 30, 2021

(With 2 figures)

\begin{abstract}
The tambaqui (Colossoma macropomum) is a fish of primary importance in South American aquaculture, principally in the Amazon region and has a particularly unique diet in the wild. Oryza spp, or Wild rice as it is commonly known, is native to the floodplains of muddy rivers in the Amazon region. The aim of this study was to analyze the physical performance and the effects of dietary levels of Oryza spp. via the hematological parameters, total food intake, conversion efficiency, growth ratio and swimming performance of this fish. Diets containing 45\% Oryza spp. induced the best performance in tambaqui. Diets containing 15\% and 30\% did not affect these indices, thus indicating that this amount of Oryza can be used as an alternative energy source for this important species within Brazilian aquaculture.
\end{abstract}

Keywords: teleosts, growth, feed evaluation, stress, blood.

\section{Crescimento e resposta hematológica do tambaqui, Colossoma macropomum alimentados com diferentes níveis de arroz, Oryza spp.}

\begin{abstract}
Resumo
O tambaqui Colossoma macropomum é um peixe de importância na aquicultura brasileira, especialmente na região amazônica. O arroz silvestre é comum nas planícies inundadas dos rios de aguas barrentas da Amazônia. O objetivo deste trabalho foi analisar os efeitos combinados do treinamento físico e dos níveis dietéticos de Oryza spp. nos parâmetros hematológicos, consumo de alimentos, eficiência de conversão, taxa de crescimento e desempenho de natação deste peixe. Dietas contendo $45 \%$ de arroz apresentaram o melhor desempenho para tambaquis. As dietas contendo $15 \%$ e 30\% não afetaram esses índices, indicando que alguma quantidade de arroz pode ser usada como fonte de energia alternativa para esta importante espécie dentro da aquicultura.
\end{abstract}

Palavras-chave: teleósteos, crescimento, avaliação de alimentos, estresse, sangue.

\section{Introduction}

The greatest obstacle to aquaculture in the Amazon region is related to the feeding of the fish (Pantoja-Lima et al., 2015a, b; Aride et al., 2018). In this sense, two problems can be identified. Firstly, the price of feed products in 
the Amazon is high because of the distance between the factories where feed is produced and the fish farms that purchase the products. Secondly, because commercial feed is generic, it may not supply the nutritional requirements of fish in this particular region (Pereira-Filho, 1995) and, in order to obtain the best performance in fish production, the fish need to receive food that has the necessary nutrients for their development (Pereira-Filho, 1995; Aride et al., 2010; Nascimento et al., 2020).

Over the past decades, several studies have been conducted with the aim of developing animal feed which contain regional Amazonian products, in order to reduce costs and increase profits. According to Silva, 1997, the incorporation of fruits and seeds from the Amazon region in tambaqui diets in substitution of corn meal, significantly increased digestibility of proteins, lipids and carbohydrates, and improved dietary energy storage, indicating that regional products have potential as feed ingredients. Peach palm meal could also replace corn meal in diets for tambaqui fingerlings without hampering their growth (Mori-Pinedo, 1999). Cassava (Manihot esculenta) was also evaluated as a viable and cost-effective tambaqui diet component (Aride et al., 2016).

Wild rice is common on the floodplains of muddy rivers in the Amazon (Araújo and Goulding, 1998), and two species of wild rice are found in these areas; both of which bear grain during floods (Rubim, 1993). It forms a good source of energy, protein, vitamins, minerals and fiber, and could be an important supplementary food for some fish species from the Amazon (Pereira-Filho, 1995). Studies have been developed using rice as a dietary supplement for farmed fish. However, this food source has not yet been tested for tambaqui.

Among the species of teleost fish with commercial importance, the tambaqui (Colossoma macropomum) is the second most produced in Brazil (Gomes et al., 2010; Lima et al., 2020). In its natural environment, this species is omnivorous with a tendency towards frugivorous feeding. Floodplain creeks and lakes are its most important habitat since these regions provide a wide range of fruits (Queiroz, 1999). In captivity, tambaqui demonstrate great ability to ingest animal and plant protein, and easily adapt to artificial feeding (Aride et al., 2007). Commercial diets used in tambaqui farming have at least $36 \%$ animal protein, and this ingredient increases the cost of commercial diets. Thus, the use of agroindustrial byproducts, such as rice, as demonstrated in this study, can reduce production costs for tambaqui. This has already been demonstrated with the use of cassava (Aride et al., 2016) and camu camu (Myrciaria dubia HBK Mc Vaugh) (Aride et al., 2018).

The physiological parameters in fish are widely used to establish the state of health of these vertebrates (Castro et al., 2021; Nascimento et al., 2020a; Oliveira et al., 2017; Oliveira et al., 2016; Oliveira et al., 2015). Considering that knowledge of the state of health of a species is very important for fish farming, and in order to improve knowledge regarding supplementary feeding using regional ingredients, the aim of the present study was to explain issues regarding use of wild rice for feeding farmed tambaqui. Its specific objective was to evaluate the physiological aspects of tambaqui (C. macropomum) when their diets contained three different levels of wild rice (Oryza spp.).

\section{Material and Methods}

This study was conducted in accordance with the principles established in Guidelines for the Use of Fishes in Research, published by American Fisheries Society. The fish used in this study were purchased from the Santo Antonio farm (Rio Preto da Eva, Amazonas state, Brazil) and were transported to the Ecophysiology and Molecular Evolution Laboratory (LEEM) of the Instituto Nacional de Pesquisas da Amazônia (INPA). In the lab, the fish received prophylactic treatment and were acclimated for a period of 15 days, during which they were fed with commercial dry pellets (Purina Ltd, São Paulo); 27\% protein, $2700 \mathrm{Kcal} \mathrm{kg}^{-1}$ digestible energy and $13 \%$ water (according to the manufacturer).

The experimental design consisted of three treatments and one control group. The treatments consisted of the use of experimental diets that included the addition of $15 \%$, $30 \%$ or $45 \%$ of Oryza spp. For each treatment group and the control group, six 60-liter tanks with constant aeration and water renewal every two days were used. Each tank received eight tambaqui fingerlings weighing $30.85 \pm$ $3.82 \mathrm{~g}$ (mean $\pm \mathrm{SD}$ ) and measuring $9.4 \pm 0.5 \mathrm{~cm}$ of standard length, which were acclimated for two days. At the end of the acclimation period, the fish were fed with commercial feed for one week, and then received the test or control diet twice a day (at 9 am and $4 \mathrm{pm}$ ) for 30 days. At the end of this 30-day period, two fish from each treatment were randomly selected. They were first subjected to a stress natatorium (swimming tunnel) (Brett, 1964) to generate exercise stress and were then anesthetized with MS-222 (5 mg/L) for blood sampling, which was done by pricking the caudal vein with previously heparinized syringes.

The test diet preparation consisted of the addition of manually crushed wild rice (Oryza spp.) grains to the ground commercial diet in different proportions $(15 \%, 30 \%$ and $45 \%$ ). The control diet consisted of commercial feed that had been ground and re-pelletized with $30 \%$ water added. All the experimental and control diets were dried in an oven at $55^{\circ} \mathrm{C}$ for 12 hours after re-pelletization and were then stored at $-20{ }^{\circ} \mathrm{C}$.

At the beginning and the end of the experiment, the fish were measured (standard length) using an ichthyometer ( $1 \mathrm{~mm}$ precision) and were weighed on a semi-analytical scale with an accuracy of 0.01 gram. Response to treatments was evaluated in terms of the weight gain (WG) and specific growth rate [SGR, \%live weight/ day $^{-1}$, SGR $(\%)=100 \mathrm{x}$ $\left(\mathrm{InW}_{2}-\mathrm{InW}_{1}\right) \mathrm{x}$ time (days) where, $\mathrm{W}_{1}$ and $\mathrm{W}_{2}$ indicate the initial and final weight $(\mathrm{g})$ respectively]. The critical speed of swimming (Ucrit) was determined by exposing the fish to a $10 \mathrm{~cm} / \mathrm{s}$ minimum speed for one hour, which was gradually increased every 30 minutes, until the fish 
reached fatigue. The Ucrit value was determined according by Brett (1964).

Hematocrit $(\mathrm{Ht})$ was determined by means of the microhematocrit technique; hemoglobin concentration $(\mathrm{Hb})$ was determined using the cyanmethemoglobin method; and the circulating red blood cell (RBC) count was obtained in a Neubauer chamber with the aid of an optical microscope as utilized in the study by Nascimento et al. (2020a). Using these variables, the blood indices were determined: mean corpuscular volume (MCV), mean corpuscular hemoglobin $(\mathrm{MCH})$ and mean corpuscular hemoglobin concentration (MCHC). Glucose concentration was determined using an electronic blood glucose meter (Accu-Chek Advantage II). Plasma concentration and triglycerides were measured using commercial kits (Doles). Cortisol was determined by ELISA commercial test Kit ("DRG International, Inc. Springfield, New Jersey, USA; \#EIA-1887”).

After a normality test had been performed, the treatment groups were compared using one-way ANOVA $(\mathrm{N}=$ 20 fish per tank), and the Tukey test was used for post-hoc comparison of means at $\mathrm{P}<0.05$.

\section{Results}

The treatments with $45 \%$ wild rice showed significant differences in weight gain in relation to the control group (Table 1). The present study showed that there were significant statistical decreases in the Hb profile (Table 2) in treatment with $45 \%$ Oryza spp.

No significant increase in Ht and RBC $(\mathrm{p}<0.05)$ was observed for sedentary fishes (Table 2). The triglyceride profile decreased in plasma of fish after exercise (Table 3 ).

Significant increases in glucose and cortisol were observed after fish had been exposed to the swimming tunnel (Figure 1 and Figure 2).

\section{Discussion}

In the natural environment, the tambaqui feeds on a highly diverse range of fruits and seeds, among which wild rice makes up a large part. The fruits and seeds from flooded forests constitute a nutrient and energy bank for tambaqui (Goulding, 1980) and represent an important source of carbohydrates (Silva et al., 2003). The feed for tambaqui needs to contain the correct main nutrients in order

Table 1. Average values ( \pm SEM) for weight, length and weight gain of C. macropomum that was fed with diets supplemented with different proportions of rice.

\begin{tabular}{ccccc}
\hline \multirow{2}{*}{ Parameters } & \multicolumn{4}{c}{ Rice (\%) } \\
\cline { 2 - 5 } & Control & $\mathbf{1 5 \%}$ & $\mathbf{3 0 \%}$ & $\mathbf{4 5 \%}$ \\
\hline IW (g) & $30.4 \pm 1.8$ & $28.4 \pm 2.9$ & $35.0 \pm 6.0$ & $29.6 \pm 1.4$ \\
FW (g) & $37.7 \pm 2.3$ & $39.9 \pm 6.9$ & $39.6 \pm 6.0$ & $41.4 \pm 4.3$ \\
IL (cm) & $9.2 \pm 0.2$ & $9.2 \pm 0.2$ & $9.2 \pm 0.2$ & $9.4 \pm 0.3$ \\
FL (cm) & $9.8 \pm 0.1$ & $10.0 \pm 0.6$ & $10.2 \pm 0.7$ & $10.2 \pm 0.3$ \\
G (\%) & $0.72 \pm 0.26$ & $0.95 \pm 0.33$ & $0.45 \pm 0.15$ & $1.8 \pm 0.30$ \\
WG (g) & $18.7 \pm 6.3$ & $23.8 \pm 7.1$ & $12.4 \pm 3.9$ & $26.7 \pm 6.6$ \\
\hline
\end{tabular}

SEM: Standard error of the mean; IW: initial weight; FW: final weight; IL: initial length; FL: final length; G: specific growth rate; WG: weight gain; Means $(*)$ indicate differences between treatments and the control group.

Table 2. Average values ( \pm SEM) for hematological parameters of $C$. macropomum that was fed with diets supplemented with different proportions of rice.

\begin{tabular}{cccccc}
\hline \multirow{2}{*}{ Parameters } & & \multicolumn{4}{c}{ Rice (\%) } \\
\cline { 3 - 6 } & & Control & $\mathbf{1 5 \%}$ & $\mathbf{3 0 \%}$ & $\mathbf{4 5 \%}$ \\
\hline $\mathrm{Hb}(\mathrm{g} / \mathrm{dL})$ & Sedentary & $8.75 \pm 0.36 \mathrm{ab}$ & $8.01 \pm 0.18 \mathrm{ab}$ & $10.1 \pm 0.56 \mathrm{a}$ & $7.47 \pm 0.57 \mathrm{~b}$ \\
& Exercised & $10.28 \pm 0.38$ & $9.56 \pm 0.98$ & $9.05 \pm 1.04$ & $10.5 \pm 0.13^{*}$ \\
$\mathrm{Ht}(\%)$ & Sedentary & $29.2 \pm 0.7$ & $26.2 \pm 0.7$ & $26.9 \pm 0.6$ & $29.7 \pm 1.0$ \\
& Exercised & $31.5 \pm 0.3$ & $31.5 \pm 1.7 *$ & $28.0 \pm 1.7$ & $30.5 \pm 1.7$ \\
$\mathrm{RBC}($ million $/ \mu \mathrm{L})$ & Sedentary & $2.1 \pm 0.03$ & $1.97 \pm 0.32$ & $1.74 \pm 0.45$ & $2.28 \pm 0.09$ \\
& Exercised & $2.48 \pm 0.22$ & $2.89 \pm 0.44^{*}$ & $2.76 \pm 0.24 *$ & $2.64 \pm 0.07$ \\
$\mathrm{MCV}(\mathrm{fL})$ & Sedentary & $139.0 \pm 53.96$ & $151.8 \pm 38.02$ & $128.24 \pm 17.53$ & $131.28 \pm 22.09$ \\
& Exercised & $130.62 \pm 12.81$ & $114.91 \pm 13.08$ & $103.98 \pm 11.57$ & $115.31 \pm 15.47$ \\
$\mathrm{MHC}(\mathrm{pg})$ & Sedentary & $41.60 \pm 1.74$ & $45.06 \pm 8.95$ & $49.32 \pm 8.86$ & $32.99 \pm 2.86$ \\
& Exercised & $42.14 \pm 2.43$ & $34.19 \pm 3.16$ & $33.09 \pm 3.87$ & $39.78 \pm 0.83$ \\
$\mathrm{MCHC}(\mathrm{g} / \mathrm{dL})$ & Sedentary & $29.94 \pm 1.10$ & $30.61 \pm 1.25$ & $37.51 \pm 1.44$ & $25.4 \pm 2.9$ \\
& Exercised & $32.66 \pm 1.45$ & $30.24 \pm 2.13$ & $33.21 \pm 5.08$ & $34.67 \pm 1.55$ \\
\hline
\end{tabular}

Data are noted with SEM (standard error of the mean). Significant differences (Tukey's HSD post-hoc test; $\mathrm{p}<0.05)$ among the treatments and the control group are noted with different superscript letters. Significant differences (Tukey's HSD post-hoc test; $\mathrm{p}<0.05$ ) between the sedentary and exercised groups, for each treatment, are noted with $\left(^{*}\right)$. 
Table 3. Average ( \pm SEM) plasma metabolite levels of C. macropomum that was fed with diets supplemented with different proportions of rice.

\begin{tabular}{cccccc}
\hline \multirow{2}{*}{ Parameters } & \multicolumn{5}{c}{ Rice (\%) } \\
\cline { 2 - 5 } & & Control & $\mathbf{1 5 \%}$ & $\mathbf{3 0 \%}$ & $\mathbf{4 5 \%}$ \\
\hline Total proteins $(\mathrm{g} / \mathrm{dL})$ & Sedentary & $2.93 \pm 0.22$ & $3.24 \pm 0.31$ & $3.13 \pm 0.10$ & $3.30 \pm 0.14$ \\
& Exercised & $3.66 \pm 0.22$ & $4.17 \pm 0.22$ & $4.14 \pm 0.11^{*}$ & $3.98 \pm 015^{*}$ \\
\multirow{2}{*}{ Triglycerides (mg/dL) } & Sedentary & $214.3 \pm 25.0$ & $245.5 \pm 54.4$ & $313.1 \pm 121.3$ & $199.1 \pm 44.1$ \\
& Exercised & $119.7 \pm 7.8^{*}$ & $137.6 \pm 7.2$ & $136.6 \pm 3.7$ & $131.2 \pm 5.0$ \\
\hline
\end{tabular}

SEM, standard error of the mean. Means with different superscript letters are significantly different $(\mathrm{p}<0.05)$.

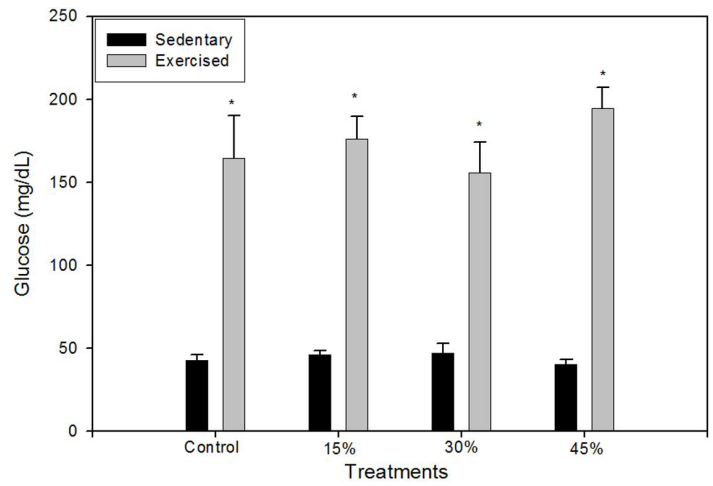

Figure 1. Average values ( \pm SEM) for plasma glucose in Colossoma macropomum that was fed with diets supplemented with different proportions of wild rice. Significant differences (Tukey's HSD post-hoc test; $\mathrm{p}=0.05$ ) among the groups are noted with different superscript letters.

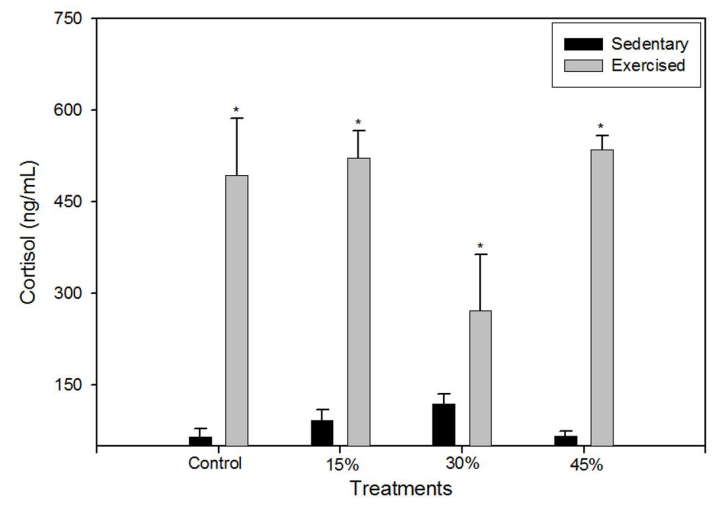

Figure 2. Average values ( \pm SEM) for plasma cortisol in C. macropomum that was fed with diets supplemented with different proportions of rice.

to achieve a balanced diet, and provide enough energy to meet their metabolic needs (Mori-Pinedo, 1999). Studies related to tambaqui feeding in their natural environment have been developed in order to identify available products and their energy rates, which makes possible the inclusion of these in diets (Silva et al., 2003; Aride et al., 2016; Aride et al., 2018).

Rice has $28 \%$ carbohydrate and carbohydrate is essential for metabolic functions such as nourishment of cells and proper functioning of the central nervous system
(Institute of Medicine, 2002). Our results suggest that Oryza spp. can be incorporated into the feed of tambaqui at proportions of $15 \%$ and $45 \%$ for the best effect on growth. Teixeira et al. (2010) described the same results for Pseudoplatystoma fasciatum that received supplementary rice meal. Gonçalves et al. (2005) found that it was possible to replace corn or soybeans with rice in the diets of tilapias. Pezzato et al. (2002) reported that rice bran was one of the most energy-rich substitute ingredients tested for tilapia (Oreochromis niloticus). These authors reported that rice meal had a binder effect, which is a favorable feature for aquaculture feed, given that it reduces dissolution of the feed and thus nutrient losses.

$\mathrm{Hb}, \mathrm{RBC}$ and $\mathrm{Ht}$ are considered to be hematological indices showing the primary response of the red blood cell parameters. They indicate the ability to transport oxygen through the blood and its use by the body (Randall, 1982), however, they can also to be used to indicate nutritional status (Aride et al., 2007; Aride et al., 2010). Barros et al. (2002) studied the addition of small amounts of cotton seed meal to the diet of Atlantic salmon (Salmo salar) and observed that this substance did not cause alterations in $\mathrm{Ht}$ and $\mathrm{Hb}$. Nevertheless, progressive decreases in hemoglobin and hematocrit levels were observed by Rinchard et al. (2003) in the same species, after the fish were fed increasing amounts of gossypol, which is an anti-nutritional factor in cotton seed. This was confirmed by Colin-Negrete et al. (1996), who suggest that high amounts of gossypol increase the fragility of red blood cells and may alter hematological indices. The present study showed a statistically significant decrease in the $\mathrm{Hb}$ profile of the fishes while under treatment with $45 \%$ of Oryza, and this causes breathing problems for tambaqui. The same result was described by Vechklang et al. (2011) for Nile tilapias (Oreochromis niloticus) that were fed with a diet that consisted of residues from rice wine. However, one possible reason for reductions in hemoglobin levels may be related to absorption of dietary iron.

No significant increase in $\mathrm{Ht}$ and $\mathrm{RBC}(\mathrm{p}<0.05)$ was observed in any of the groups (Table 2), thus suggesting that the addition of Oryza to the diet does not alter the metabolic oxygen demand profile, such as described for Atlantic salmon by Barros et al. (2002). Similarly to the aforementioned study, in the study by Aride et al. (2016) where cassava was used in tambaqui feed, increased $\mathrm{Ht}$ and $\mathrm{Hb}$ levels were reported, which suggested that use of cassava may also cause increased metabolic oxygen 
demand. All hematological values for this study were within the ranges that were reported by Mariano et al. (2017) for tambaqui. Organic changes caused by feeding are usually verified through stress agents (Aride et al., 2010; Ferreira et al., 2013). Oliveira (2005) used the critical swimming speed (Ucrit) as a stressor to assess the nutritional status of tambaqui that were fed with fruits and seeds from wetlands as a supplement, and noted that the hemoglobin concentration and erythrocyte counts of fish that were submitted to swimming stress showed a tendency to increase.

According to Tavares-Dias and Sandrim (1998), stressed teleosts fish present hematological changes (Houston et al., 1996) and these changes may result from hemoconcentration or hemodilution, which is caused by osmoregulatory dysfunction. Furthermore, according to Weber et al. (2003), this dysfunction may occur through an attempt to supply the metabolic demand for oxygen, since swimming is an activity with high energy demands and, depending on the species, the requirement may be very high.

We observed increased total protein levels in plasma in the tambaqui fed with all the diets $(15,30$ and $45 \%$ Oryza spp.) when compared with the control diet. Similar results were described by Aride et al. (2016) for tambaqui that were fed diets containing cassava (Manihot esculenta). These results suggest that total protein synthesis was occurring from carbohydrate reserves. Decreased total protein levels are associated with nutrient-deficient diets (Aride et al., 2016). Carbohydrates are stored in the liver of fish as glycogen, and this is degraded depending on the required energy demand, with glucose as a resulting product (Mommsen et al., 1999). Increased plasma cortisol values are frequently associated with subsequent elevation of plasma glucose and lactate levels (Barton, 2002), as showed in our results after the fish were exposed to swimming stress. Glucose is distributed to the tissues via blood, and its levels increase through reduction in its use for energy production, through stimulation of glycogenolysis from hormonal induction (Vijayan and Monn, 1992) or even due to stressful situations (Hochachka and Somero, 1984).

Season, diet and time of last food intake also affect glucose blood levels (Wedemeyer et al., 1990). The increased glucose levels in the present study were within the normal range for fish and did not affect their growth. Similar results were also seen for jundiá (Rhamdia quelen) that were exposed to an acute stressor (Koakoski et al., 2012). A similar result was obtained by Gomes et al. (2003) for tambaqui and Ferreira et al. (2013) for matrinxã (Brycon amazonicus). Mobilization of glucose occurs as a means of providing the extra energy needed to overcome the stress imposed (Barton and Iwama, 1991). Our results show that the hyperglycemia observed among tambaqui after exercise may have been maintained by high levels of cortisol, which originated through glycogenolysis in the liver (Mommsen et al., 1999). Similar results were described by Aride et al. (2016) in tambaqui that received a diet supplemented with cassava.
Our results showed that the addition of Oryza spp. to the diet of Colossoma macropomum caused increased weight gain and a higher specific growth rate without changing the physiological parameters of the species.

\section{Acknowledgements}

This research was supported by Conselho Nacional de Desenvolvimento Científico e Tecnológico CNPQ (554009/2006-4 OMEGA). The authors are grateful to the Support Program for Scientific Development and Technological Innovation (PADCIT) of the Federal Institute of Education, Science and Technology of Amazonas (IFAM) (proclamation nos. 008/2014, 001/2016 and 002/2020), for the projects "Physiological parameters and Cichla spp. of Balbina lake: support for management and conservation and applicability for fish farming", "Monitoring of the welfare of fish of economic importance for the state of Amazonas" and "Physiology of Aquatic Organisms in the Amazon".

\section{References}

ARAÚJO, C.L. and GOULDING, M., 1998. Os frutos do tambaqui: ecologia, conservação e cultivo na Amazônia. Tefé, AM: Sociedade Civil Mamirauá, 186 p.

ARIDE, P.H.R., FERREIRA, M.S., DUARTE, R.M., OLIVEIRA, A.M., FREITAS, D.V., SANTOS, A.L.W., NOZAWA, S.R. and VAL, A.L., 2010. Ascorbic acid (Vitamin C) andiron concentration in tambaqui, Colossoma macropomum, iron absorption. Journal of the World Aquaculture Society, vol. 41, no. 2, pp. 291-297. http://dx.doi.org/10.1111/j.1749-7345.2010.00370.x.

ARIDE, P.H.R., OLIVEIRA, A.M., BATISTA, R.B., FERREIRA, M.S., PANTOJA-LIMA, J., LADISLAU, D.S., CASTRO, P.D.S. and OLIVEIRA, A.T., 2018. Changes on physiological parameters of tambaqui (Colossoma macropomum) fed with diets supplemented with Amazonian fruit Camu camu (Myrciaria dubia). Brazilian Journal of Biology $=$ Revista Brasileira de Biologia, vol. 78, no. 2, pp. 360-367. http://dx.doi.org/10.1590/1519-6984.169442. PMid:28954015.

ARIDE, P.H.R., OLIVEIRA, A.T., OLIVEIRA, A.M., FERREIRA, M.S., BAPTISTA, R.B., SANTOS, S.M. and PANTOJA-LIMA, J., 2016. Growth and hematological responses of tambaqui fed different amounts of cassava (Manihot esculenta). Arquivo Brasileiro de Medicina Veterinária e Zootecnia, vol. 68, no. 6, pp. 1697-1704. http://dx.doi.org/10.1590/1678-4162-8704.

ARIDE, P.H.R., ROUBACH, R. and VAL, A.L., 2007. Tolerance response of tambaqui (Cuvier) to water $\mathrm{pH}$. Aquaculture Research, vol. 38, pp. 588-594. http://dx.doi.org/10.1111/j.13652109.2007.01693.x.

BARROS, M.M., LIM, C. and KLESIUS, P.H., 2002. Effect of soybean meal replacement by cottonseed meal and iron supplementation on growth, immune response and resistance of Channel Catfish (Ictalurus puctatus) to Edwardsiella ictaluri challenge. Aquaculture, vol. 207, no. 3-4, pp. 263-279. http:// dx.doi.org/10.1016/S0044-8486(01)00740-2.

BARTON, B.A. and IWAMA, G.K., 1991. Physiological changes in fish from stress in aquaculture with emphasis on the response and effects of corticosteroids. Annual Review of Fish Diseases, vol. 1, pp. 3-26. http://dx.doi.org/10.1016/0959-8030(91)90019-G. 
BARTON, B.A., 2002. Stress in fishes: a diversity of responses with particular reference to changes in circulating corticorteroids. Integrative and Comparative Biology, vol. 42, no. 3, pp. 517-525. http://dx.doi.org/10.1093/icb/42.3.517. PMid:21708747.

BRETT, J.R., 1964. The respiratory metabolism and swimming performance of young sockeye salmon. Journal of the Fisheries Research Board of Canada, vol. 21, no. 5, pp. 1183-1226. http:// dx.doi.org/10.1139/f64-103.

CASTRO, P.D.S., LADISLAU, D., RIBEIRO, M.W.S., LOPES, A.C.C., LAVANDER, H.D., BASSUL, L.A., MATTOS, D.C., LIEBL, A.R.S., ARIDE, P.H.R. and OLIVEIRA, A.T. 2021. Hematological parameters of three species of tucunarés (Cichla spp.) from Lake Balbina, Presidente Figueiredo, Amazonas. Brazilian Journal of Biology, ahead of print. https://doi.org/10.1590/1519-6984.219409.

COLIN-NEGRETE, J., KIESLING, H.E., ROSS, T.T. and SMITH, J.F., 1996. Effect of whole cottonseed on serum constituents, fragility of erythrocyte cells, and reproduction of growing Holstein heifers. Journal of Dairy Science, vol. 79, no. 11, pp. 2016-2023. http:// dx.doi.org/10.3168/jds.S0022-0302(96)76574-8. PMid:8961108.

FERREIRA, M.S., ARIDE, P.H.R., SILVA, M.N.P. and VAL, A.L., 2013. Efeito da quantidade de proteína na dieta e treinamento físico sobre parâmetros fisiológicos e zootécnicos de matrinchã (Brycon amazonicus, Günther 1869). Acta Amazonica, vol. 43, no. 4, pp. 439-446. http://dx.doi.org/10.1590/S0044-59672013000400005.

GOMES, L.C., ROUBACH, R., ARAUJO-LIMA, C.A.R.M., CHIPPARI-GOMES, A.R., LOPES, N.P. and URBINATI, E.C., 2003. Effect of fish density during transportation on stress and mortality of juvenile of tambaqui Colossoma macropomum. Journal of the World Aquaculture Society, vol. 34, no. 1, pp. 76-84. http://dx.doi.org/10.1111/j.1749-7345.2003.tb00041.x.

GOMES, L.C., SIMÕES, L.N. and ARAUJO-LIMA, C.A.R.M. 2010. Tambaqui (Colossoma macropomum). In: BALDISSEROTTO, B. and GOMES, L.C. Espécies Nativas para piscicultura no Brasil. 2. ed. Santa Maria: Editora UFSM, pp. 175-204.

GONÇALVES, G.S., PEZZATO, L.E., BARROS, M.M., KLEEMAN, G.K. and ROCHA, D.F., 2005. Efeitos da suplementação de fitase sobre a disponibilidade aparente de $\mathrm{Mg}, \mathrm{Ca}, \mathrm{Zn}, \mathrm{Cu}, \mathrm{Mn}$ e $\mathrm{Fe}$ em alimentos vegetais para tilápia-do-Nilo. Revista Brasileira de Zootecnia, vol. 34, no. 6, pp. 2155-2163. http://dx.doi.org/10.1590/ S1516-35982005000700001.

GOULDING, M. 1980. The fishes and the forest explorations in Amazonian Natural History. University of California Press, Berkeley, 280 p. http://dx.doi.org/10.1525/9780520316133.

HOCHACHKA, P.W. and SOMERO, G.N., 1984. Limiting oxygen availability. In: P.W. HOCHACHKA and G.N. SOMERO. Biochemical Adaptation. Princeton: Princeton University Press, pp. 145-181.

HOUSTON, A.H., ROBERTS, W.C. and KENNINGTON, J.A., 1996. Hematological response in fish: pronephican splenic involvements in the goldfish, Carassius auratus L. Fish Physiology and Biochemistry, vol. 15, no. 6, pp. 481-489. http://dx.doi. org/10.1007/BF01874922. PMid:24194357.

INSTITUTE OF MEDICINE, 2002. Dietary Reference Intakes - Energy, Carbohydrate, Fiber, Fat, Fatty Acids, Cholesterol, Protein, and Amino Acids. Washington, D.C.: The National Academy Press. Energy, Cap. 6, Part 1, pp. 6.1-6.57.

KOAKOSKI, G., OLIVEIRA, T.A., ROSA, J.G.S., FAGUNDES, M., KREUTZ, L.C. and BARCELLOS, L.J.G., 2012. Divergent time course of cortisol response to stress in fish of different ages.
Physiology \& Behavior, vol. 106, no. 2, pp. 129-132. http://dx.doi. org/10.1016/j.physbeh.2012.01.013. PMid:22289300.

LIMA, C.A.S., MACHADO BUSSONS, M.R.F., DE OLIVEIRA, A.T., ARIDE, P.H.R., DE ALMEIDA O'SULLIVAN, F.L. and PANTOJA-LIMA, J., 2020. Socioeconomic and profitability analysis of Tambaqui Colossoma macropomum fish farming in the state of Amazonas, Brazil. Aquaculture Economics \& Management, vol. 1, pp. 1-16. http://dx.doi.org/10.1080/1365 7305.2020.1765895.

MARIANO, W.S., SOUSA, F.L.G., TAVARES-DIAS, M., RODRIGUES, R.L.C., AZEVEDO, S.B. and LIMA, J.O., 2017. Estudo hematológico de tambaqui (Colossoma macropomum) submetido à concentração subletal de biopesticida a base de Bacillus thuringiensis. Revista Sodebras, vol. 12, pp. 54-58.

MOMMSEN, T.P., VIJAYAN, M.M. and MOON, T.W., 1999. Cortisol in teleost: Dynamics, mechanism action, and metabolic regulation. Reviews in Fish Biology and Fisheries, vol. 9, no. 3, pp. 211-268. http://dx.doi.org/10.1023/A:1008924418720.

MORI-PINEDO, L.A., 1999. Determinação das exigências protéicocalóricas de alevinos de Tambaqui (Colossoma macropomun, Cuvier, 1818). Manaus, Amazonas: Instituto Nacional de Pesquisa da Amazônia, Fundação Universidade do Amazonas, 100 p. Doctoral Thesis.

NASCIMENTO, G.B., AMARAL, L.V., RAMOS, N.C., LITAIFF, N.R., RIBEIRO, M.W.S., LADISLAU, D.S., ARIDE, P.H.R. and OLIVEIRA, A.T., 2020a. Parâmetros hematológicos do matrinxã Brycon amazonicus (Characidae: Bryconinae) criados em cativeiro na região Amazônica. Brazilian Journal of Development, vol. 6, no. 1, pp. 3303-3315. http://dx.doi.org/10.34117/bjdv6n1-238.

NASCIMENTO, M.S., MATTOS, B.O., BUSSONS, M.R.F.M., OLIVEIRA, A.T., LIEBL, A.R.S. and CARVALHO, T.B., 2020. Supplementation of citric acid in plant protein-based diets for juvenile tambaqui. Journal of the World Aquaculture Society, vol. •., pp. 1-13. http://dx.doi.org/10.1111/jwas.12735.

OLIVEIRA, A.M., 2005. Aspectos fisiológicos e bioquímicos do tambaqui (Colossoma macropomum, Cuvier,1818) alimentado com dietas suplementadas por frutos e sementes de áreas alagadas. Manaus, Amazonas: Instituto Nacional de Pesquisa da Amazônia, Fundação Universidade do Amazonas, 73 p. Master's Thesis.

OLIVEIRA, A.T., ARAÚJO, M.L.G., LEMOS, J.R.G., SANTOS, M.Q.C., PANTOJA-LIMA, J., ARIDE, P.H.R., TAVARES-DIAS, M. and MARCON, J.L., 2017. Ecophysiological interactions and water-related physicochemical parameters among freshwater stingrays. Brazilian Journal of Biology $=$ Revista Brasileira de Biologia, vol. 77, no. 3, pp. 616-621. http://dx.doi.org/10.1590/15196984.01816. PMid:27783760.

OLIVEIRA, A.T., PANTOJA-LIMA, J., ARIDE, P.H.R., TAVARESDIAS, M. and MARCON, J.L., 2015. Fisiologia de arraias de água doce: subsídios para aplicabilidade na aquicultura. In: M. TAVARES DIAS and W.S. MARIANO, orgs. Aquicultura no Brasil: novas perspectivas. São Carlos: Pedro \& João, 1. ed., vol. 1 , pp. $45-74$

OLIVEIRA, A.T., SANTOS, M.Q.C., ARAUJO, M.L.G., LEMOS, J.R.G., SALES, R.S.A., PANTOJA-LIMA, J., TAVARES-DIAS, M. and MARCON, J.L., 2016. Hematological parameters of three freshwater stingray species (Chondrichthyes: Potamotrygonidae) in the middle Rio Negro, Amazonas state. Biochemical Systematics and Ecology, vol. 69, pp. 33-40. http://dx.doi.org/10.1016/j. bse.2016.07.002 
PANTOJA-LIMA, J., SANTOS, S.M., OLIVEIRA, A.T. ARAUJO, R. L., SILVA JUNIOR, J.A.L., BERNARDINO, G., ALVES, R.R.S., FERRAZ FILHO, A., GOMES, A.L. and ARIDE, P.H.R., 2015a. Pesquisa e transferência de tecnologia aliadas para desenvolvimento da aquicultura no Estado do Amazonas. In: M. TAVARES DIAS and W.S. MARIANO, orgs. Aquicultura no Brasil: novas perspectivas. São Carlos: Pedro \& João, 2. ed., vol. 2, pp. 313-332.

PANTOJA-LIMA, J., SANTOS, S.M., Oliveira, A.T., ARAUJO, R. L., SILVA JUNIOR, J.A.L. and ROCHA, P.H.A., 2015b. Pró-rural aquicultura: relatos das principais ações de extensão tecnológica e um panorama do setor aquícola do estado do Amazonas, Brasil. Nexus, vol. 1, pp. 35-45.

PEREIRA-FILHO, M., 1995. Alternativas para a alimentação de peixes em cativeiro. In: A.L. VAL and A. HONCZARYK. Criando peixes na Amazônia. Manaus: MCT, INPA, pp. 75-82.

PEZZATO, L.E., MIRANDA, E.C., BARROS, M.M., PINTO, L.G.Q., FURUYA, W.M. and PEZZATO, A.C., 2002. Digestibilidade aparente de ingredientes pela tilápia do Nilo (Oreochromis niloticus). Revista Brasileira de Zootecnia, vol. 31, no. 4, pp. 1595-1604. http://dx.doi.org/10.1590/S1516-35982002000700001.

QUEIROZ, H.L., 1999. A pesca, as pescarias e os pescadores de Mamirauá. In: H.L. QUEIROZ and W.G.R. CRAMPTON. Estratégias de manejo para recursos pesqueiros na reserva de desenvolvimento sustentável Mamirauá, Brasília: Sociedade Civil Mamirauá, MCT/CNPq, pp. 37-71.

RANDALL, D., 1982. The control of respiration and circulating in fish during exercise and hipoxia. The Journal of Experimental Biology, vol. 100, pp. 275-288.

RINCHARD, J., LEE, K.J., DABROWSKI, K., CIERESZKO, A., BLOM, J.W. and OTTOBRE, J.S., 2003. Influence of gossypol from dietary cottonseed meal on haematology, reproductive steroids and tissue gossypol enantiomer concentrations in male rainbow trout (Oncorhynchus mykiss). Aquaculture Nutrition, vol. 9, no. 4, pp. 275-282. http://dx.doi.org/10.1046/j.1365-2095.2003.00253.x.

RUBIM, M.A.L., 1993. A case study on life-history of wild rice - From germination to emergence of inflorescence. In:
H. MORISHIMA and P.S. MARTINS. Investigations of Plant Genetic Resources in the Amazon Basin with Emphasis on the Genus Oryza. São Paulo: MISRP/FAPESP.

SILVA, J.M., PEREIRA-FILHO, M. and PEREIRA, M.I.O., 2003. Valor nutricional e energético de espécies vegetais importantes na alimentação do tambaqui. Acta Amazonica, vol. 33, no. 4, pp. 87-700. http://dx.doi.org/10.1590/S0044-59672003000400014.

TAVARES-DIAS, M. and SANDRIM, E.F.S., 1998. Características hematológicas e teleósteos brasileiros. I. Série vermelha e dosagem de cortisol e glicose do plasma sanguíneo de espécies de Colossoma macropomun em condições de cultivo. Acta Scientiarum, vol. 20 , pp. $157-160$

TEIXEIRA, E.A., SALIBA, E.O.S., EULER, A.C.C., FARIA, P.M.C., CREPALDI, D.V. and RIBEIRO, L.P., 2010. Coeficientes de digestibilidade aparente de alimentos energéticos para juvenis de Surubim. Revista Brasileira de Zootecnia, vol. 39, no. 6, pp. 1180-1185. http://dx.doi.org/10.1590/S1516-35982010000600003.

VECHKLANG, K., BOONANUNTANASARN, S., PONCHUNCHONNVONG, S., PIRARAT, N. and WANAPU, C., 2011. The potentional for rice wine residual as an alternative protein source in a pratical diet for Nile tilapia (Oreochromis niloticus) at the juvenile stage. Aquaculture Nutrition, vol. 17, no. 6, pp. 685-694. http://dx.doi.org/10.1111/j.1365-2095.2011.00870.x.

VIJAYAN, M.M. and MONN, T.W., 1992. Acute handling stress alters hepatic glycogen metabolism ion food deprived rainbow trout (Onchorinchus mykiss). Canadian Journal of Fisheries and Aquatic Sciences, vol. 49, no. 11, pp. 2260-2266. http://dx.doi. org/10.1139/f92-247.

WEBER, L.P., HIGGINS, P.S., CARLSON, R.I. and JANZ, D.M., 2003. Development and validation of methods for measuring multiple indices of condition in juvenile fishes. Journal of Fish Biology, vol. 63, no. 3, pp. 637-658. http://dx.doi.org/10.1046/ j.1095-8649.2003.00178.x.

WEDEMEYER, G., BRUCE, B.A. and MCLEAY, C.J., 1990. Methods for fish biology. Bethesda, USA: American Fisheries Society, pp. 451-489. 